\title{
"Tis a shameful confession": steam power and the Pacific maritime labor community
}

\section{John T. Grider}

Des millénaires durant, l'on a utilisé la voile et le vent pour la navigation à travers les océans et les mers du monde. Néanmoins, à la fin du dix-neuvième siècle de nombreux marins se sont rendu compte que l'industrie maritime est devenue une industrie à la vapeur, et que s'ils voulaient gagner leur vie en mer ils étaient obligés de s'adapter à cette nouvelle mode de propulsion. Les marins qui ont décidé de rester en mer, que ce soit à bord de navires côtiers ou de large, ont reconnu le besoin d'employer de nouvelles stratégies afin de protéger l'identité de leur travail et de leur communauté, et d'exiger de leurs employeurs de meilleures conditions de travail et de salaire. Mais l'animosité raciale entre les marins a compliqué leur milieu de travail et a introduit des vulnérabilités face à leurs employeurs. La présence d'asiatiques en mer à la fin du XIXe siècle a érodé la tolérance raciale qui avait jadis marqué la communauté maritime.

In 1925, Charles W. Brown criticized the younger generation of sailors who only had experience aboard steamships. Brown wrote about his boyhood heroes, officers and crewmen who "were men - bold, brave, honest, adventurous - men who did something, who made their mark on their generation, who acquired a vast fund of practical knowledge from hard experience, diligent study, and travel all over the world." He then went on to mock the heroes of the youths of the 1920s writing, "Comparing my boyish ideals with Charlie Chaplin, Jack Dempsey, and rich, unprincipled speculators of the present day overcome by money-madness and greed, it seems to me the old Master Mariners stand well by comparison." ${ }^{1}$ Brown, who rose through the ranks to become a captain, criticized the overly tender and unmanly way that young men learned their trade aboard steamers. According to Brown, "Other qualities were demanded from sailors fifty years ago than those which are required today." Brown lamented that "Activity, adaptability, and all-around skill are not needed by seamen as they were in the days of the supremacy of the American sailing ship." ${ }^{2}$ Brown's mockery illustrates his contempt for the effect that steam had on the seafaring community and his longing for a time when going to sea meant becoming a heroic, manly figure.

1 Charles W. Brown, My Ditty Bag (Boston: Small, Maynard and Company, 1925), 6.

2 Ibid., 16-17.

The Northern Mariner/Le marin du nord XXIV, No. 2 (April 2014), 111-133 
Steam technology forever altered the maritime industry. For thousands of years, men had used wind and sail to propel their vessels across the world's oceans and seas. Sailing required men to possess special knowledge and skills that allowed them to make sense of the maze of masts, ropes, and canvas every sailing vessel possessed, and separated them from working-class people on shore. During the nineteenth century, steam slowly replaced sail, making the ancient nautical technology and the men skilled in the older technology obsolete. At first, sailors who had learned their trade under canvas resented the steam technology and the men willing to work below decks in the new engine rooms. A. J. Villiers, once a sailor himself, wrote that steamers might not always be able to "proudly honk along, defiant of the sea. There are times...for the exercise of sea-skill in no small degree... if disaster is to be averted, when initiative is the quality most demanded of her officers. And if they fail? Well, the steamer may not be defiant of the sea any more." Villiers also discussed the character building elements that accompanied sail, stating, "If the boy comes aboard a little weak and without much strength of character, the example of his shipmates will soon rectify matters and it will be quite a different boy who returns. The weak are made strong, the strong strengthened." According to the author, "there is the value of the actual seamanship experienced that the boy gets in sail that he would never get in steam." Villiers believed that sailing ships cast a spell upon those who went to sea: "And the spell is this - that it makes them men. Who does not want to be a man?"3

By the late nineteenth century, however, many sailors realized that the maritime industry had become a steam industry, and that if they wished to make their living at sea they had to adapt themselves to the new mode of propulsion. Many sailors abandoned the sea altogether, prefering to take advantage of opportunities on land, or simply growing weary of life at sea. Other sailors found opportunities in coastal trading where sail remained the dominant mode of trasportation far longer than it did in trans-Pacific shipping. The sailors who decided to remain at sea, whether aboard coastal or deepwater vessels, realized that they needed to employ new strategies in order to protect their labor identity and community, and secure better working conditions and wages from their employers.

But racial animosity between sailors complicated labor issues and made seamen vulnerable to their employers. Asian presence at sea in the late nineteenth century eroded the racial tolerance that had once marked the maritime community as a place where virtually anyone, rich or poor, white or black, Christian or polytheist, could find the opportunity to work, start a career, seek adventure, or escape shoreside responsibilities. In the nineteenth-century Pacific, new racial and cultural groups entered the maritime industry. Some groups, such as the Pacific Islanders, fit well into traditional maritime society and often enhanced and contributed to the labor community and identity found among sailors. According to non-Asian seamen, Asians, and the Chinese in particular,

3 A. J. Villiers, Falmouth for Orders: The Story of a Sailing Race around Cape Horn (Garden City, New York: Garden City Publishing Company, Inc., 1929), 188, 190-193. Villiers wrote his book in part to convince the British Admiralty that training in sail should be compulsory for officers and crew. 
did not mesh well with the established maritime community and their presence threatened to destroy the labor community's long held traditions and values. Early experiences with the Chinese on land and at sea and the incredible influx of Chinese men into the maritime labor force towards the end of the century unfairly prejudiced traditional Atlantic seamen against the newcomers. Most non-Asian seamen probably would have agreed with British Inspector General of Chinese Maritime Customs Robert Hart's assessment of the Chinese when he wrote: "Our Chinese friends have too much 'stay' — and yet too little 'backbone' in them: they are like an air-ball - it remains the same size, but gives way wherever pushed." 4

Non-Asian sailors in the Pacific, more familiar with the Atlantic maritime tradition than their Asian counterparts, united together in attempts to unionize sailors aboard both sailing and steam vessels. By the 1880 s, non-Asian seamen tended to ignore the differences between men who worked with sail and men who worked with steam. Instead, non-Asian sailors focused on their corporate employers' abuses and racial differences in the Pacific maritime community. Asians became a convenient scapegoat for non-Asian sailors in the late nineteenth century Pacific. As the union movement among non-Asian seamen grew, the maritime labor community became bifurcated along racial lines. During the second half of the nineteenth century, the maritime industry witnessed the opening of the Pacific to capitalist markets, the transformation from sail to steam, and the racially-motivated fracturing of the labor community at sea.

By the first half of the nineteenth century, steam locomotion was already in use in the maritime industry. American and European steamboat technology was originally developed for inland waterways and not for ocean-going vessels. ${ }^{5}$ Inventors and investors realized that early steam engine technology would be inadequate for dealing with the much rougher conditions at sea, which in turn might lead to a loss of investment and interest in the new form of locomotion. In addition, applying steam to deep sea vessels presented a laundry list of logistical problems. Early steam engines relied on coal as their fuel source and ships could not make long voyages, or short ones, for that matter, without carrying large quantities of coal in their holds or making frequent stops at refueling ports and stations. For the time being, steam was relegated to lakes, rivers, and harbors, and used for transporting goods and passengers to and from urban areas. By the $1820 \mathrm{~s}$, steam-powered ferries, tugboats, and barges dotted northeastern United States' inland waterways and became a regular and growing feature on every navigable river and lake in the U.S. ${ }^{6}$

The way steam was used in the early days of its maritime development may have reflected in part the low opinion sailors had of the technology. Sailors saw the ocean as a

4 Letter 874 to F. L. Campbell of the Foreign office, January 15, 1893 in John King Fairbank, Katherine Frost Bruner, Elizabeth MacLeod Matheson, eds., The I.G. in Peking: Letters of Robert Hart, Chinese Maritime Customs, 1868-1907 (London: The Belknap Press, 1975), II: 917.

5 John H. Morrison, History of American Steam Navigation (New York: W.F. Sametz, 1903), 5-385.

6 Ibid., 46-59. 
unique environment that tested a man's skills, physical strength, emotional well-being, and courage. Boatmen on lakes and rivers may have worked on water craft, but they were by no means sailors. From Herman Melville we get a sense of how seamen felt about inland waterways. In Moby Dick, Ishmael relates a story about a conversation he had in the Golden Inn in Lima with a group of "Spanish friends." Ishmael tells his audience about a mutiny that occurred aboard the whaleship Town-Ho. One of the main characters in the story was a "Lakeman" named Steelkilt who sailed the North American Great Lakes. Melville takes great care in describing the Lakeman, "though an inlander," as "wild-ocean born" and "as much of an audacious mariner as any." The author also goes to great lengths to assure his audience that "those grand fresh-water seas of ours... possess an ocean-like expansiveness, with many of the ocean's noblest traits; with many of its rimmed varieties of races and of climes." Melville goes on to claim that the vessels on the lakes "are swept by Borean and dismasting blasts as direful as any that lash the salted wave," again suggesting that the freshwater Great Lakes are themselves oceans, rife with the dangers and challenges of their saltwater counterparts.

Although Melville does not directly disparage lakes and rivers, or the men who work upon them, he certainly suggests that seamen commonly found fresh water sailors inferior by presenting the Great Lakes as an exception to other inland waterways and by pointing out their "ocean-like" qualities. In his story, Ishmael also tells his Spanish friends that Great Lakes sailors shipped out "in square-sail brigs and three-masted ships, well nigh as large and stout as any that ever sailed out of your old Callao to far Manilla." Melville again attempts to legitimize the Great Lakes' maritime qualities by pointing out that the vessels sailing on those saltless oceans were the same as the ships sailing on the Atlantic, Pacific, and Indian oceans. Melville goes even further in his description of the lakes by pointing out their cosmopolitan and exotic aspects. Melville argues that the lakes "contain round Achipelagoes of romantic isles, even as the Polynesian waters do... are shored by two great contrasting nations, as the Atlantic is...they yield their beaches to wild barbarians...those same woods harboring wild Afric beasts of prey." For Melville, experienceing foreignness and change were central to the true sailing experience and most inland waterways did not provide these crucial elements. Inland waterways represented the mundane and predictable, a place where greenhorns, hayseeds, and lubbers lived and a place that sailors rejected. ${ }^{7}$

During the mid-nineteenth century, American steamships were essentially seaworthy versions of river, lake, and sound steamers built in the United States. ${ }^{8}$ Because steam technology first made its appearance on lakes and rivers, sailors may have perceived steam power as an inland waterway technology and not fit, either practically or symbolically, for the sea. Sailors worked in an environment in constant flux. Swells,

7 Herman Melville, Moby Dick, or The Whale, (New York: Humphrey Milford, 1920), 293295.

8 John Haskel Kemble, "Side-Wheelers Across the Pacific," The American Neptune 2 (January 1942): 7; Morrison, History of American Steam Navigation, 406-514; Edward D. Beechert, Honolulu: Crossroads of the Pacific (Columbus, South Carolina: University of South Carolina Press, 1991), 77. 
rollers, and waves made their workplace one of perpetual change and danger, which was crucial to the development of their maritime identity. Lakes and rivers did not change, remaining static and predictable and thus were not nearly as dangerous as the ocean. Sailors also lived and worked at sea for months or years at a time, removing them from shoreside communities and families. Inland boatmen could return to their homes and families regularly, distancing them from the homosocial atmosphere of life at sea.

Steamers began to make their presence felt in the Pacific world along China's rivers and coastlines. The first known steamer in China was the Forbes, constructed by the Howrah Dock Company of Calcutta. The Forbes, a small paddle steamer, arrived at Macao on 18 April 1830, but shortly returned to Calcutta because adequate coal could not be found to operate the engines properly, illustrating the logistic need for coal stations. On 15 May 1845, the first American steamer, the Midas, arrived at Hong Kong from New York. For the next year the Midas made two round trips per week between Hong Kong and Canton before sinking during a salvage venture to Manila. ${ }^{9}$ Several American companies began to run steamers along China's rivers and coastlines, including Russell and Company, the Shanghai Steam Navigation Company, Augustine Heard and Company, and Olyphant and Company. The China steamers did not include deep water vessels, and the farthest ranging steamships only went as far as Japan and the Phillipines. Most steamers in Asia were relegated to rivers and coatlines because a system of coal stations had not been established, making long distance voyages all but impossible. ${ }^{10}$ By the late 1840 s, however, a small but determined and growing number of deepwater, oceangoing steamships began to arrive in the Pacific.

Trans-Atlantic steamship services began in 1819 when the American ship Savannah sailed from New York to Liverpool. But the British soon dominated the steamship industry and American steamers did not provide regular service until the late 1840s. The United States reasserted itself in the steamship industry after Congress authorized the Postmaster General to create ocean mail contracts in 1845. In 1847 the United States Mail Company and the Pacific Mail Company were organized and each received a $\$ 200,000$ annual government subsidy. The United States Mail Company was responsible for the Atlantic mail, and the Pacific Mail Company's service included stops between the Panamanian Isthmus and the Columbia River. From 1847 to 1848, the Pacific Mail sent the California, the Panama, and the Oregon to service its Pacific coastal route. Other steamship companies attempted to establish themselves in the Pacific, including the Empire City Line, the United States Mail Steamship Company, the Nicaragua Transit Company, the Central American Transit Company, and the North American Steamship Company, but none could adequately compete with the Pacific

9 Edward Kenneth Haviland, “American Steam Navigation in China, 1845-1878, Part I," The American Neptune 16 (July 1956):158-161.

10 Kwang-Ching Liu, Anglo-American Steamship Rivalry in China, 1862-1874 (Cambridge, Massachusetts: Harvard University Press, 1962), 93, 130; Andrew Porter, Victorian Shipping, Business and Imperial Policy: Donald Curie, the Castle Line and Southern Africa (New York: The Boydell Press, 1986), 41, 45-47, 114; from a letter dated 17 January 1883, in which Robert Hart comments on the expense, availability, and quality of coal in China, Fairbank et al., The I.G. in Peking, 1:443. 
Mail. From 1865 to 1875 , the Pacific Mail expanded its fleet and extended its services from California to Japan, China, New Zealand, and Australia and increased its role in the coastal trade in the eastern Pacific. This expansion was due in part to the 1865 Congressional legislation that awarded the Pacific Mail with a $\$ 500,000$ annual subsidy to open a mail line to Yokohama and Hong Kong. In the late 1870s the Pacific Mail also won mail contracts from the Canadian, New Zealand, and New South Wales governments. In 1875, the Pacific Mail reached its peak, boasting 40 steamships in its merchant armada. By the late 1870 s, steam powered vessels were a regular sight in every part of the Pacific, and their presence would change the Pacific maritime world forever. ${ }^{11}$

In 1915, Hubert Howe Bancroft wrote, "A dozen lines of steamships, or thereabout, now crosses the Pacific between America and Asia... Ships comprising scores of lines ply along shore, unite the islands and mainland, or sail direct for foreign ports." 12 The Pacific, however, lagged behind the Atlantic regarding the transition from sail to steam, and as late as 1885 sailing vessels still outnumbered steam vessels. ${ }^{13}$ The Atlantic possessed far more shipyards in both the United States and Europe, but as the nineteenth century wore on fewer and fewer sailing vessels could be seen in the Pacific. However, the days of Pacific sail were numbered. ${ }^{14}$ Richard Henry Dana returned to the coast of California as a tourist in the 1860s and marvelled at the changes he saw: "the steamer Senator makes regular trips up and down the coast, between San Francisco and San Diego, calling at intermediate ports." ${ }^{15}$ Dana's comment suggests that not only had the California coast become more populated and integrated into a global market economy, but that steamers were a regular presence in these Pacific waters. In 1868, George Chase,

11 John Haskell Kemble, "A Hundred Years of the Pacific Mail," The American Neptune 10 (April 1950):123-143; Morrison, History of American Steam Navigation, 406, 408, Fred Erving Dayton, Steamboat Days (New York: Frederick A. Stokes Company, 1925), 362; Norman E. Tutorow, "Leland Stanford, President of the Occidental and Oriental Steamship Company: A Study in the Rhetoric and Reality of Competition," The American Neptune 31 (April 1971):120-129; On 5 September 1851, San Francisco's Daily Alta California listed the steamships owned by the major American shipping companies in the Pacific. The Pacific Mail Steamship Company owned the Golden Gate, Illinois, Oregon, Panama, California, Tennessee, Northerner, Republic, Antelope, Isthmus, Unicorn, Carolina, Columbus, Constitution, Fremont, Sarah Sands, and Columbia; Vanderbilt Independent Lines owned the Pacific, Independence, North America, Sea Bird, San Francisco, and Gold Hunter; Empire City Line owned the New Orleans, Commodore Stockton, Monumental City, Peru, Chili, Coquimbo, Equator, and New Grenada.

12 Hubert Howe Bancroft, The New Pacific (New York: The Bancroft Company, 1913), 1-2.

13 Paul S. Taylor, The Sailors' Union of the Pacific (New York: The Ronald Press Company, 1923), 8. According to Taylor, there were 18,564 sailing vessels and 8,398 steam vessels registered in the U.S. in 1885. By 1922, however, there were only 5,399 sailing vessels and 18,960 steam vessels. Taylor does not, however, provide statistics on how many seamen were sailing on each type of vessel.

14 Tom H. Inkster, "Last Days of Sail of the North Pacific or Bound for Bering Sea," American Neptune 39 (July 1979):184-189.

15 Richard Henry Dana, Two Years Before the Mast (New York: Walter J. Black, 1930), 387. 
a passenger on a cruise from California to Maine aboard the Colorado, kept a journal of his voyage. Somewhere off the coast of Central America on 11 September the Colorado "passed the Steamer Constitution, bound up for San Francisco...A short time after, we passed the coasting Steamer Parkerson...also saw a sailing vessel off about 10 miles, the first one I've seen since we left San Francisco." 16 The Colorado had left San Francisco in late August and travelled along the busy California coast. That Chase had not seen a sailing vessel after travelling for over two weeks highlights the slow demise of sail and the ascendence of steam in the Pacific. Just ten or fifteen years before Chase wrote his journal, steamships would have been a relatively rare sight, even along the coast, and sailing vessels, including the impressive clippers, would have been commonplace.

For long distance and trans-Pacific voyages, sailing vessels, which did not rely on a limited fuel supply, were superior to steamships until the 1870s. During a cruise between San Francisco and Panama in 1849, the Pacific Mail steamer California did not have enough coal to complete its run. C. Forbes, the California's master, wrote: "burning all the Wood we can rake together...This is close running, our coal is very low and very little wood left but I must reach soundings [even] if I cut off the Bullwarks as my Ship is very light \& the current very Strong out of the Bay. If I drift to Sea there is no telling when I will get back again, perhaps never." ${ }^{17}$ The early steamships that sailed the Pacific were hybrid vessels that carried both steam engines and sails. Long distances, inadequate coal supplies, and the unpredictability of early steam engine models made sails an essential part of early steam powered vessels at sea. ${ }^{18}$ Several photos and paintings of steamships in the Pacific from the 1850s through the 1870 s clearly show masts, rigging, and sails at either end of the ships. This was especially true for the side paddle-wheel ships that were notoriously inefficient to operate, but which dominated American steamship design well into the 1870 s. ${ }^{19}$ The early steamships relied heavily on sails, only using their engines when they faced unfavorable winds and seas, or when leaving and entering port. When naval lieutenant John M. Brooke and his crew accompanied the Japanese naval vessel Kanrin Maru to San Francisco in 1860, the ship carried only six days of coal in its hold for a voyage that lasted thirty-seven days. Most of the voyage was spent under sail and Brooke marvelled at the vessel's sailing ability, writing, "The

16 Journal and Letters Recording Journey from California to Maine, August-September, 1868, Bancroft Library, University of California Berkley [hereafter, BANC] MSS C-F 117.

17 "Journal of a Voyage from San Francisco to Panama via Monterey, Santa Barbara, San Diego, Mazetlan, San Blas \& Acapulco-1849. Stemer California, C. Forbes, Master," in California Gold Rush Voyages, 1848-1849, John E. Pomfret, ed., (San Marino, California: The Huntington Library, 1954), 240-241.

18 Charles Bateson, Gold Fleet for California: Forty-Niners From Australia and New Zealand (East Lansing, Michigan: Michigan State University Press, 1963), 12; Richard V. Francaviglia, From Sail to Steam: Four Centuries of Texas Maritime History, 1500-1900 (Austin, Texas: University of Texas Press, 1998), 136-138.

19 Aboard the United States Coast and Geodetic Survey ship C. P. Patterson, T. Dewey wrote home to his mother that his ship had made over 10 knots "with all sail and steam." When speed was needed, both sail and steam could be employed. T. Dewey letters, BANC MSS 71/98z. 
ship lies to beautifully under close reefed maintopsail and fore storm staysail." 20

Early steamships thus still required crews with seamen experienced with sails, rigging, and wind behavior, and this protected the skills and value of seamen for a while. But steam technology improved greatly over the course of the nineteenth century as shipbuilders developed new technologies and took cues from locomotive engineers. Shipbuilders replaced the inefficient paddle-wheel propulsion system found on early steam vessels with screw propulsion. Screw propulsion greatly enhanced efficiency and increased speed by placing a propeller under the stern of a vessel. Unlike paddlewheels, which tended to come out of the water when a vessel rolled in heavy seas, screw propellers usually remained below the waterline. Paddlewheels also had the disadvantage, according to one critic, of having "five sixths of the paddle surface... constantly out of the water, and in action against the air." 21 Screw propellers reduced wind resistance greatly, thus further contributing to greater steam engine efficiency. Transition from wooden hulls to iron hulls also improved steamships during the nineteenth century, making the vessels lighter, larger, more durable, and more resistant to fire. $^{22}$

Better constructed boilers and engines allowed for higher pressure and greater horsepower, eventually making sails unnecessary even for long-distance voyages. ${ }^{23}$ American shipbuilders and investors resisted many of the new technologies, insisting that wooden sailing and paddle-wheeled vessels were adequate for the tasks of the United States merchant marine. British maritime technological achievements, however, gave them an advantage over American merchant activities. Great Britain's shipbuilding so greatly outdistanced American shipbuilding that after the Civil War that most American iron-hulled, screw-propelled steamships were built in foreign shipyards. British maritime profits, combined with American timber shortages in the 1860s and 1870s, and advancements in American iron production, forced shipbuilders in the United States to transition to iron-hulled, screw propeller, steamships. ${ }^{24}$ The use of steam also had consequences for the men who worked at sea.

Steam technology completely altered the hierarchy and work patterns aboard

20 George M. Brooke, Jr. John M. Brooke's Pacific Cruise and Japanese Adventure, 1858-1860 (Honolulu: University of Hawaii Press, 1986), 226. The sails aboard the hybrid steamships were few, and the main topsail and the staysail represented some of the most important of a steamships sailing equipment.

21 Thomas R. Heinrich, Ships for the Seven Seas: Philadelphia Shipbuilding in the Age of Industrial Capitalism (Baltimore: The Johns Hopkins University Press, 1997), 15-18.

22 Captain James Williamson, The Clyde Passenger Steamer: Its Rise and Progress during the Nineteenth Century, From the 'Comet' of 1812 to the 'King Edward' of 1901 (Glasgow: James MacLehose and Sons, 1904), 67-80.

23 Ibid., 301-317.

24 Lawrence C. Allin, "The Civil War and the Period of Decline: 1861-1913," in Robert A. Kilmax, ed., America's Maritime Legacy: A History of the U.S. Merchant Marine and Shipbuilding Industry Since Colonial Times (Boulder, Colorado: Westview Press, 1979), 6770; Heinrich, Ships for the Seven Seas, 17. 
ships. Before steam, a ship's complement included officers, petty officers, seamen, and specialists. Ships' officers included the master and one or more mates; aboard large vessels with many crewmembers, boatswains and quartermasters constituted the petty officers; able bodied seamen, ordinary seamen, and boys made up the crew; and cooks, stewards, sailmakers, and carpenters made up the specialists, also known as "idlers." With the introduction of steam came new petty officers, in the form of engineers, and crewmen, in the form of firemen and coal-passers. Steamships split seamen into three separate categories; the deck crew, who were responsible for the outside of the vessel; engine crews who were responsible for the engines; and steward's crews, who waited on officers and passengers. ${ }^{25}$ Even aboard the early hybrid steamers the deck crew became less necessary, and the skills associated with sailing became less valuable. This trend towards sailor obsolescence increased dramatically towards the end of the nineteenth century as fewer and fewer steamers were built with masts and sails. As a result, deck sailors became increasingly deskilled. Cephus Pearl, a Canadian deck sailor aboard a hybrid steamer in 1884, wrote, "work consists mostly of washing and scrubbing, and whoever can use a holystone can be an AB [able bodied seaman]." Another Canadian seaman, Benjamin Doane, wrote, "With the vanishing of sails, the sailor and his peculiar skill are obsolete, and the word 'sailor' is a figure of speech." Their increasingly obsolete status made deck crews, including officers, the minority aboard steamships. By the end of the nineteenth century, able bodied and ordinary seamen made up only about 25 percent of steamship crews. In short, the true "sailor" was being replaced by the engineer and fireman, and sailing men had reason to worry about their future on the seas. ${ }^{26}$

For seamen, steam had one huge disadvantage; fire. Galley stoves, personal cooking fires, and careless smokers made any wooden vessel a potential fire hazard, but a coal fired furnace in the very heart of the ship made seamen particularly nervous. John Baxter Will, a Scottish seaman who worked his way through the ranks to become a captain, did not much care for steamships, especially the American wooden, paddlewheel vessels. Will traveled aboard the wooden paddle-wheeler Oregonian and later wrote, "She was the first ship I was afraid being on board at sea." Will continued by stating, "These old wooden paddle steamers, all the time I was in them, looked to me like match boxes; if fire once started, nothing could stop it although the fire hoses were stretched regularly every night." ${ }^{27}$ The highly experienced Will had sailed on almost every type of ship afloat during his career, but only the wooden steamers gave him cause for concern. The record of wooden steamships lost to fire justified Will's fear of the highly flammable ships. Between 1848 and 1868, the Pacific Mail had 21 wooden sidewheelers built for its various Pacific routes. From 1869 to 1878, the company lost twelve steamships, three of which caught fire and burned. To put these numbers into

25 Taylor, The Sailors' Union of the Pacific, 10-11.

26 Eric W. Sager, Seafaring Labour: The Merchant Marine of Atlantic Canada 1820-1914 (Montreal and Kingston: McGill-Queens University Press, 1989), 260-262; Williamson, The Clyde Passenger Steamer, 260-293.

27 George Alexander Lensen, ed., Trading Under Sail Off Japan, 1860-99: The Recollections of Captain John Baxter Will, Sailing-Master \& Pilot (Tokyo: Sophia University, 1968), 116117. 
perspective, within a nine year period the Pacific Mail lost over fourteen percent of its side-wheel fleet, and almost eight percent of its total fleet of forty vessels, to fire. ${ }^{28}$ When the Pacific Mail's ships burned from fire hazards such as flammable cargoes like coal, there was considerable loss of life.

For example, on 24 August 1872, the America burned in Yokohama Harbor. Ironically, the America's boilers did not start the fire and could have actually prevented the tragedy. Instead the fire started in the steerage quarters which were being used to store hay for the animals on board the ship. At about eleven o'clock at night the ship's quartermaster smelled smoke during a routine inspection and found the stored hay ablaze. Since the America lay in port, the steam pressure in its boilers had been allowed to go down. The steam that remained in the boilers was so low that it could not provide adequate pressure to the fire hoses and the crew, though willing, had no hope of fighting the blaze. The fire rapidly spread, and in less than an hour all hands abandoned ship. Pandemonium broke out aboard the America and passengers, mostly Chinese steerage passengers, scrambled to rescue their belongings. Many passengers jumped overboard weighed down by their possessions and drowned. Others were killed when fellow passengers threw heavy trunks and boxes over the railing and onto their heads. A ladder near the front of the ship broke as panicked passengers over burdened it, forcing many to jump blindly into the harbor. Boats from nearby vessels pulled several to safety, but fifty-three Chinese, three European, and three Japanese passengers perished in the conflagration.

Fire aboard steamships and steamboats was such a problem that Congress established the Steamboat Inspection Service under the Department of Commerce in 1852. In addition, Congress passed over forty laws, several of which required engineers to be licensed and demanded proof of masters', mates', and pilots' competence. Engineers resented the steamboat regulations and resisted attempts by inspectors to enforce the regulations. Despite the federal government's legislative activities, accidents continued to occur aboard steamships, often resulting in a great many deaths. Although most sailors feared fire aboard steamships, other accidents occurred that sent steamships and men to the bottom. Between 1853 and 1878, the Pacific Mail lost fourteen steam vessels, thirty-five percent of its total merchant fleet, in addition to the three lost to fire. Although most of the wrecks did not result in any deaths, a total of 555 deaths did occur on five of the wrecked ships, the most catastrophic being the Hermann, aboard which 275 people perished on Point Kwatzu, Japan. ${ }^{29}$ Sailing vessels, although an extremely

28 Kemble, "A Hundred Years of the Pacific Mail," 130, 133-134. Kemble, "Side Wheelers Across the Pacific," 36-37. The America burned throughout the night and into the next day. To prevent the fire from spreading to other ships or the city, attempts were made to sink the America with gun powder, but the blaze did not stop until rain and a steam fire engine, placed aboard a tug, extinguished the flames. Only the burned out hull, which later sank, remained. The cause behind the fire remains a mystery, but rumor had it that locals set the ship ablaze because of resentment towards the Pacific Mail for hiring Chinese crews and hopes of looting Chinese passengers. 
dangerous place to work, seemed benign and welcoming when compared to the potential holocaust aboard steamers. Sailors accepted and willingly faced the dangers associated with living and working at sea, but fire represented a danger that sailors could rarely overcome, and seamen reluctantly served aboard ships that, in essence, left port already ablaze. $^{30}$

Steamship catastrophes took so many lives because steam-powered vessels carried so many more passengers than most sailing vessels. Passengers had crowded aboard barks, schooners, clippers, and anything else that could float since 1849, determined to reach the gold fields in California and later in Australia. Before the Gold Rush, passengers had only occasionally traveled to the Pacific, usually to distant Pacific Islands as missionaries. But the population boom on the North American west coast after 1849 changed the nature of passenger travel in the Pacific. During the Gold Rush, very few women and children made the journey to the Pacific and most ships headed to California carried young men as passengers. As steamship companies provided more regular service along the North American coast and to Asia, and gold seekers and merchants established themselves in growing California communities, however, more and more women, children, and entire families made the voyage to the Pacific. Businessmen, laborers, missionaries, tourists, and government officials also started to cross the wide ocean between the United States and Asia more regularly, creating a market for passenger travel along regularly scheduled steamship routes. ${ }^{31}$

In 1884, the City of Tokio listed a white stewardess among its mostly Chinese crew, and in the journal he kept during his cruise aboard the Colorado, George Chase mentions a stewardess who brought him a bowl of gruel one Sunday morning. With women among a steamships steward's crew, how could seamen maintain the manly identity they had created based on their labors at sea? The sea had been a male domain for centuries, and women aboard seagoing vessels, not as passengers but as a regular part of the crew, would have changed and threatened the male homosocial world at sea. Captains' wives, daughters, mothers-in-law, and missionary and settler women had traveled aboard vessels in the Pacific for decades. Women at sea tended many of the domestic chores aboard a vessel, such as nursing ill or injured sailors back to health, holding eligious services, and making sure that the crew was properly clothed, especially when the women were related to the captain. ${ }^{32}$ Women crewmembers, however, were novel, and an unwelcome challenge to sailors' manly identity and sense of professional

30 Nineteenth century steamship disasters also occurred in the Atlantic, with about the same frequency and loss of life. William Henry Flayhart III, Perils of the Atlantic: Steamship Disasters, 1850 to the Present (New York: W. W. Norton \& Company, 2003),17-18; Williamson, The Clyde Passenger Steamer, 44-66.

31 Bancroft, The New Pacific, 1-13.

32 Joan Druett, Hen Frigates: Wives of Merchant Captains under Sail (New York: Simon \& Schuster, 1998), 78-79, 139. David Cordingly, Women Sailors and Sailors' Women: An Untold Maritime History (New York: Random House, 2001), 109-115. The quote is from a Letter from the Union Mutual Insurance Company, New York, 18 February 1857, as found in Cordingly. Mary Patten became a celebrity in San Francisco for commanding the ship and was mobbed by reporters when she arrived in port. 
worth, even when those women worked as domestic servants. Aboard steamships, men had begun to lose their monopoly on maritime labor and identity. Such a challenge to sailors' identity and marketable skills would have only increased seamen's animosity towards steamships and those who sailed them. But service oriented crewmembers were not the only new maritime laborers that challenged sailors' position in the maritime community.

Firemen and coal-passers aboard steamships highlighted the deskilling of sailors "trained before the mast," and created a schism within the maritime community. While working with sail required months if not years of intensive training at sea, even the most inexperienced landsman could work as a fireman or coal-passer after a relatively short initiation. A whaling sailor and officer, Frank T. Bullen, wrote, "what is wanted in a steamer is only a burly labourer who is able to steer." ${ }^{33}$ Increasingly, seamen's ability to splice ropes, climb rigging, furl and unfurl sails, and pull the proper lines when necessary became obsolete. The trend towards obsolescence continued more rapidly later in the nineteenth century as iron-hulled ships that relied solely on steam power replaced wooden-hulled steamers equipped with sails.

Transoceanic telegraph cables placed further limitations on officers and crews aboard steamships by forcing regular contact with company officials who informed captains of their destinations and the goods they were to purchase and at what price. Before steam and telegraphs, captains had a great deal of freedom and possessed a considerable amount of knowledge about local weather patterns and markets. In essence, steam and telegraph cables reduced seamen and officers from traders and merchants to delivery boys. Although sailing vessels could seem like prisons to seamen, they also provided a sense of freedom and adventure as they sailed towards unknown ports and encountered unknown obstacles. Steamships, however, plodded along in a predictable and mundane fashion cruise after cruise. ${ }^{34}$

Sailing required seamen to work outside in the fresh air and sunshine, and sailors only went below decks when they needed to sleep or escape bad weather. The lower decks on sailing vessels were cramped, dark, and wet, and a place to be avoided whenever possible. Firemen and coal-passers, however, worked exclusively in the bowels of steamships, roasted by intense coal fires and without the benefit of sunlight or fresh air. Working in a ship's engine room was also a physically grueling job that taxed the stamina of all who did it. Heaving coal into a furnace for several hours a day was difficult enough, but the need for fewer seamen aboard a steamer, and the desire to cut expenses and increase profits, made the task far more difficult. One sailor reported that the work on a steamer "was too hard so we quit."35 With fewer crewmen aboard steamships, officers pushed their men harder, giving steamers a reputation for being

33 Frank T. Bullen, The Men of the Merchant Service: Being the Polity of the Mercantile Marine for Longshore Readers (New York: Frederick A. Stokes, 1900), 257-259.

34 John A. Butler, Sailing on Friday: The Perilous Voyage of America's Merchant Marine (Washington: Brassey's 1997), 106.

35 Captain H. E. Raabe, Cannibal Nights: The Reminiscences of a Free-lance Trader (New York: Payson \& Clarke, Ltd., 1927), 75. 
places where employer brutality was common. Harsh treatment aboard steamers became so common that the National Seamen's Union of America started publishing a "Red Record," which reported cases of extreme abuse and listed the names of the officers responsible. ${ }^{36}$ The hard, unskilled labor and harsh treatment found on steamships initially caused most sailing men to avoid working on them when possible and despise the men who had no experience with sail.

In the 1870s, H. E. Raabe witnessed an event that illustrates sailors' hostility towards steamships and those who worked them. At the Solomon Islands a group of beachcombers approached the captain of the sailing vessel Emma P. about securing berths aboard his vessel. The captain said that he needed more hands, but worried that the beachcombers did not "look much like sailors." One of the men explained that they had deserted a steamer and that he had been a fireman and his comrades had been "coalpassers." The Emma P.'s captain responded by asking, "Ever sailed before the mast, pulled an oar or handled sail? I got no use for firemen." ${ }^{37}$ The captain's statements show his contempt for firemen and their lack of sailing skills. Sailing ships needed skilled men who knew the sea, and although the beachcombers had experience at sea, they were not sailors in the captain's eyes. Most mariners trained before the mast agreed with this bias and continued to view steam with suspicion throughout the century.

Economic issues also tainted sailors' perception of steamers and steamship crews. Sailing men believed that their skilled work deserved better pay than that received by firemen and coal-passers, who did low- or unskilled labor. ${ }^{38}$ When sailors received comparable or lower wages than firemen and coal-passers, they most likely grew angry. An unknown author aboard the Edith $K$. Couillard, a wooden-hulled, sail-rigged steamship that arrived in San Francisco in 1849, wrote in his journal on 23 March, "This day has given the men information of their wages being raised to $\$ 100$ per month and all officers in proportion." The author does not mention how much the crew made before reaching California, but it is safe to assume that they were probably making anywhere from $\$ 15$ to $\$ 30$ per month. In addition, the author does not mention any difference in pay between sailors, firemen, and coal-passers. Although the sailors aboard the Edith K. Couillard would certainly have appreciated the inflated California wage rates, they probably would have resented the same increase for the unskilled coal-passers. The journal's author makes no reference to the crew's state of mind beyond mentioning that the "ships company" was "slightly affected" by "gold fever." Officers hoped that the pay raise would break the sailors' gold fever. However, three men deserted the ship on 25 March despite the pay increase. ${ }^{39}$

Aboard the Hawaiian steamer James Makee in 1882, the five seamen aboard made $\$ 10$ per run from Honolulu to San Francisco, but the three firemen made $\$ 15$ per run. Even the officers made less money than their counterparts in the engine room. The

36 Butler, Sailing on Friday, 106-107. Druett, Hen Frigates, 80.

37 Raabe, Cannibal Nights, 75.

38 Walter Licht, Working for the Railroad: The Organization of Work in the Nineteenth Century (Printeon: Princeton University Press, 1983), 79-124.

39

Ships' Logs, 1838-1851 BANC MSS 93/136p. 
chief mate made $\$ 60$ per run to San Francisco and the second mate made $\$ 30$ per run. The second engineer, however, made $\$ 100$ per run and the third engineer made $\$ 80 .^{40} \mathrm{In}$ 1885 , the six seamen aboard the Hawaiian steamer Planter received $\$ 30$ per month while the six men in the engine room made $\$ 45$ per month. The Planter's chief mate made $\$ 75$ and the second mate made $\$ 45$ per month, while the first and second assistant engineers made $\$ 125$ and $\$ 100$ per month respectively. ${ }^{41}$ The discrepancy in pay does not seem to have anything to do with the officers' possible racial biases. All of the sailors and firemen listed in the two shipping articles had European names. It is possible that some of the sailors shipping out of Honolulu were Hawaiians who had converted to Christianity and adopted Anglo-Saxon names, but this seems unlikely given that most Hawaiian converts used Christian first names, but kept Hawaiian surnames. The difference in wage rates clearly occurred based on the different work done by seamen and engine room men, and illustrates the devaluing of seamen by the later part of the nineteenth century. ${ }^{42}$ Despite this contempt for steam, however, economic realities often forced sailors to serve aboard ships that used the technology. John Cameron grudgingly admitted, "Tis a shameful confession I now must make: I forsook sail and dallied with steam - this in the service of the Inner-Island Steam Navigation Company, which operated a fleet of vessels between Honolulu and the outlying islands of Hawaii." ${ }^{43}$

Chief Engineer Thomas J. Winship's log seems to support the opinion that firemen and coal-passers had a more gruelling and punishing job than other seamen. Of the nineteen men who served under Winship, two were discharged due to disability, two were released due to illness, and two were taken to a hospital onshore when they became too sick to work. ${ }^{44}$ Illness and disability occurred on every vessel during the nineteenth century, but Winship lost almost a third of his crewmen to injury and disease over an eighteen month period. ${ }^{45}$ Working in the intense heat and foul, dusty and smoky air of

40 Honolulu Harbor Master's Shipping Articles, 1882. John Cameron was the first mate aboard the James Makee at this time.

41 Honolulu Harbor Master's Shipping Articles, 1885. John Cameron was the master of the Planter at this time.

42 According to Eric W. Sager, on board British "Saint John Steamers" and "Auxiliary Steamers" in the Atlantic between 1863 and 1914, able seamen made an average of $\$ 19.26$, Canadian, per month, and ordinary seamen made an average of $\$ 12.15$ per month. Firemen during the same time period made an average of $\$ 21.15$ per month, and "trimmers," or coalpassers, made $\$ 10.77$ per month. First, second, and third mates made an average of $\$ 43.89$ per month while chief engineers made $\$ 71.10$, second engineers made $\$ 59.07$, third engineers made \$38.96, and fourth engineers made \$24.80. Sager, Seafaring Labour, 247. Andrew Farrell, John Cameron's Odyssey (New York: Macmillan, 1928), 215-216. Cameron writes that he was the captain of the steamer James Makee in 1883 and the captain of the steamer Planter in 1886, both out of Honolulu.

44 Engineer's Log of US Revenue Steamer Shubrick, (C. M. Scammon Captain) H. H. Andrews Lieutenant Commanding, 14 June 1865-9 December 1866: Thomas J. Winship, Chief Engineer.

45 Eleanora C. Gordon, "The Captain as Healer: Medical Care on Merchantmen and Whalers, 1790-1865," The American Neptune 54 (Fall 1994):265-277. 
the engine room seems to have taken its toll on the Shubrick's engineering department. Such working conditions may have led officers to pay engine room men more money and allow firemen and coal-passers greater liberty in compensation for their difficult job. ${ }^{46}$

Sailors wishing to continue to work at sea often had to swallow their pride and accept berths on steamships, either working for less money on deck, or more money in the engineering department. Moving down to the engine room paid better, but it forced men used to working in the fresh air inside the stale hull of the ship where they had to learn how to perform new tasks. While in San Francisco, Frank S. Redfield wrote to his brother in 1852, "I have not yet been able to find anything to do though I expect a berth on a steamboat if I can get it." A sailing man, Redfield would have found service on the steamboat doubly aggravating since it was a steam powered vessel that operated within the confines of San Francisco Bay. Redfield's tenure on the steamboat did not last long; he soon quit. Convinced of his own skills as a sailing man, Redfield questioned the steamboat owner's competency, writing in 1853, "I was only about six weeks on board the steamer owing to trouble I had with the owner of her he did not know how to handle her and would not give me a chance...I allow no man to stand on the forward deck and tell me how to keep my helm when I am pilot." By 1885, Redfield was looking for a berth on "a foreign voyage." ${ }^{47}$ Redfield's difficulties with his employer had much to do with his pride and identity as a sailor. Having a great deal of skill and experience as a seaman, Redfield resented his subordinate position on an inland waterway boat to a man he considered inexperienced and incompetent. Redfield, like so many other sailors did not respect steam technology or the men who worked with it.

There were, however, new skills associated with work aboard steamships. Firemen had to know how to tend their machines and keep fires burning evenly and cleanly; coal-passers had to learn how to manage their heaps of coal to prevent them from sliding about in a rolling and pitching sea; and deck crewmen had to know how to work with both wire and fiber ropes, how to secure anchors, how to operate winches and other deck machinery, how to secure and open hatches, how to lower lifeboats, and how to operate fire-fighting equipment. Although the skills required aboard steam vessels were more specialized and often less complicated than on sailing vessels, seamen still had to learn intricate tasks if they wanted to do their job efficiently and secure promotions. ${ }^{48}$ Steam became even more unpopular with sailing men, both those determined to continue working with sail and those who made the transition to steam, as the century progressed and tens of thousands of Asian men entered the maritime labor community in the Pacific.

Steam greatly deskilled the sailing profession, allowing thousands of Asian men, with no prior experience at sea, to flood the maritime job market in the Pacific, undermining the value of non-Asian sailors. During the late nineteenth century, men from China and India went to work aboard steamships and created an element of racial

$46 \quad$ Sager, Seafaring Labour, 248.

47 Frank S. Redfield Letters, BANC : ALS, 1852-1878. Letter to brother, San Francisco, 12 August 1852, letter to brother, San Francisco, 14 October 1852, letter to brother, San Francisco, 21 November 1855. 
animosity closely associated with steam that had not previously existed aboard vessels in the Pacific. Most racial animosity aboard American vessels in the Pacific targeted the Chinese. The steamboats that plied the inland waters of China and conducted the trade along the coast had Chinese crews. Non-Asian sailors who had sailed to China would have probably associated the Chinese with steamboats. Between 1845 and 1878, more than 200 steamboats and steamships operated in or around China, prompting the American consul in Shanghai George F. Seward to state "The only great success of our countrymen on steam navigation of late years has been made here on the coast of China." ${ }^{49}$ This association would have led many seamen to be skeptical of both steam and the Chinese sailors who went to sea.

Many Chinese men left their homes to work as laborers overseas, or traveled to distant lands as merchants and traders. Others decided to take advantage of the foreign shipping companies' desire to hire inexpensive, mostly unskilled labor and joined the crews of steamships. Many Chinese men who had previously worked on the local river and coastal steamers, foreign sailing vessels, and native junks and fishing boats certainly joined the deep sea and trans-Pacific steamships, bringing with them the experience gained from working with steam and sail. Of the over 78,000 Chinese men who worked aboard American steamships from 1876 to 1906, however, most had no sailing or steamboat experience when they entered the maritime service. While the majority of Chinese sailors came from the coastal provinces of Kwangtung and Fukien, and would have had some familiarity with the sea if not actual experience sailing it, many of those who went to sea from these provinces were newcomers who had fled from advancing armies and economic difficulties further inland. Chinese seamen quickly learned their jobs well and although most Chinese sailors worked in the engine rooms of foreign vessels, many also worked on deck, replacing the non-Asian sailors in the Pacific. ${ }^{50}$ NonAsian men who had joined steamships would have seen Chinese men at sea as a direct threat to their economic well-being, especially after tens of thousands of Chinese entered the merchant service as cheap laborers.

Sailors from India also started to enter the maritime labor community in large numbers with the introduction of steam power. Similar to the Chinese sailors' experience, Indian sailors had worked as replacement crews aboard foreign merchant vessels trading between Europe and Asia during the early years of contact and beyond. Most early Indian sailors working on foreign ships had native experience at sea and hailed from India's northeastern seaboard. Expanding merchant steam fleets, however, required a greater number of laborers to work in engine rooms, on deck, and in the domestic positions, and large numbers of Indians from inland areas started to fill out foreign crew lists. As colonized British subjects the vast majority of Indian seamen sailed aboard British vessels. However, many left British vessels in foreign ports and

49 Letter to George F. Seward to Mr. Cadawalader, Shanghai, 13 December 1875, Haviland, "American Steam Navigation in China, 1845-1878": 158.

50 Robert J. Schwendinger, "Chinese Sailors: America's Invisible Merhcant Marine, 18761905," California History 57 (Spring 1978): 61. 
found their way onto other European and American vessels. ${ }^{51}$ Like the Chinese sailors, Indian mariners worked for far less money than non-Asian sailors, and employers preferentially hired them over European, American, and Pacific Islander sailors. Between 1888 and 1901, the number of Indian seamen aboard British vessels doubled. In 1901, 37,431 sailors out of a total of 151,376 seamen aboard British vessels were from India, making almost one in four British sailors Indian. On ships crewed by Indians, like those crewed by Chinese, Indians tended to represent the majority of the crew. ${ }^{52}$

Non-Asian seamen would have felt out of place aboard these ships. While nonAsian seamen were often separated by language and native cultures, they shared a common maritime culture and tradition that united them in a common community and identity. With so many Asians flooding the maritime job market, there was simply not enough time to assimilate them into the traditions created in the Atlantic and refined in the Pacific aboard European and American vessels. Asian sailors had to rely on their native cultures, traditions, and identities in order to survive and hopefully prosper in the maritime world, as well as create new maritime communities, traditions, and identities. Aboard the vessels crewed primarily by Asians, only a handful of officers, engineers, boatswains, and deckhands represented the maritime tradition that had once dominated the Pacific maritime community.

Other Asians also participated in the maritime labor market as it became dominated by steam, but not in the same numbers, or with the same effect, as seamen from China and India. Filipino sailors, for example, remained a small but constant presence aboard foreign vessels throughout the century. Japanese sailors, on the other hand, largely disappeared from foreign vessels by the time steam power began to seriously alter the maritime industry.

Since Asians flooded the job market and worked for one-third less than other sailors, the economic impact on white, black, and Pacific Island seamen was often devastating. The growing Asian presence created by steam technology, however, had consequences for non-Asian seamen that directly assaulted their manly maritime identity. In order to justify colonial expansion and dominance over colonized peoples in the nineteenth century, colonial powers began to recast the image of people of color. ${ }^{53}$ Asians were cast by colonial powers as irrational, emotional, cowardly, effeminate,

51 Charles P. Low, Some Recollections by Charles P. Low: Commanding the Clipper Ships "Houqua," "Jacob Bell," "Samuel Russell," and "N.B. Palmer," in the China Trade, 18471873 (Boston: George H. Ellis Co., 1906), 159, 162.

52 Robert Prescott, "Lascar Seamen on the Clyde," T. C. Smout, ed., Scotland and the Sea (Edinburgh: John Donald Publishers, Ltd., 1992), 199-200.

53 Kristen L. Hoganson, Fighting for American Manhood: How Gender Politics Provoked the Spanish-American and Philippine-American Wars, (New Haven: Yale University Press, 1998) 11-12; Robert W. Rydell, All the World's a Fair: Visions of Empire at American International Expositions, 1876-1916 (Chicago: The University of Chicago Press, 1984), 28; Nicholas Thomas, Colonialism's Culture: Anthropology, Travel, and Government (Princeton: Princeton University Press, 1994); 14-23, Daniel R. Headrick, The Tools of Empire: Technology and European Imperialism in the Nineteenth Century (New York: Oxford University Press, 1981), 43-54. 
childlike, simple-minded, and backward. ${ }^{54}$ In other words, Asians did not share the manly qualities possessed by middle-class white Americans and Europeans. Employers used these racial stereotypes to justify low wages, poor food and lodging, and harsh discipline provided to Asian seamen.

Employers also used these stereotypes to emasculate white seamen. Maritime employers had always considered sailors undisciplined, dependent, and childlike and used these supposed characteristics as an excuse to replace them with Asian seamen during the steamship era. Employers claimed that white seamen lacked virtues that Asian sailors possessed; namely, docility, diligence, and sobriety. ${ }^{55}$ By making such claims, employers purposefully suggested that seafaring no longer required manly qualities like strength, bravery, and skill. This suggestion directly targeted sailors' manly identity. Seamen's inability to live up to middle class standards of masculinity had caused them to embrace the manly qualities that a life at sea did possess and that men shoreside recognized. If working at sea no longer required manliness from sailors, seamen had no identity as men. Because Asians made their appearance in the maritime community in large numbers with the introduction of steam, non-Asian seamen associated Chinese, Indians, and other Asians with steam technology and the dissipation of the maritime tradition and manly maritime identity they had known.

Steam technology changed the way men worked at sea and, for men who invested a great deal of their identity on the labor they did, created a cultural crisis for seamen. During the nineteenth century, the manly identity and community aboard vessels faded as canvas made way for coal. A. J. Villiers wrote, "in comparison with the sailing ship, the steamer is only a sea-factory." ${ }^{, 56}$ As with factories on land, sea-factories deskilled and devalued the men who worked on them, and forced sailors to redefine and reevaluate their chosen profession. Unable to rely on their labor for manly identity, sailors had to seek new strategies and actions to define themselves and their community. Blaming technology and Asian seamen, who were already removed from the white, black, and Pacific Islander tradition, seamen, primarily from northwest European nations, united in the Pacific in a last-ditch effort to save what was left of their traditions, community, and identity. In attempting to salvage their way of life, sailors from the Atlantic tradition aided in dismantling their own maritime community by abandoning racial tolerance. White sailors became increasingly racially exclusive during the late nineteenth century, targeting Asians for exclusion from the maritime profession. As a result, the Pacific maritime community fragmented, and the maritime labor identity created in the Atlantic virtually disappeared in the Pacific.

Many Pacific seamen saw their best hope for their future as sailors and men in the creation of an industrial maritime union. As one maritime labor leader explained at

54 Laura Tabili, “'A Maritime Race’: Masculinity and the Racial Division of Labor in British Merchant Ships, 1900-1939," in Margaret S. Creighton and Lisa Norling, eds., Iron Men, Wooden Women: Gender and Seafaring in the Atlantic World, 1700-1920 (Baltimore, MD: Johns Hopkins University Press, 1996),180.

55 Ibid., 181, 186.

56 Villiers, Falmouth for Orders, 191. 
the end of the century, "An organization of men lives on and by the ideal by which it is dominated...We wanted to learn to so conduct ourselves as to be able to reconquer our standing amongst our fellows as men and the standing of our calling." 57 Several unsuccessful attempts were made to create a seamen's Union in the Pacific during the late nineteenth century. ${ }^{58}$ Despite early failures to create a maritime union in the Pacific, Pacific sailors succeeded in forming the Coast Seamen's Union in 1885. Still, the union had a narrow membership. The Coast Seamen's Union initially only included men who worked on sailing vessels in the various coastal trades on the North American west coast. The union also saw Asian seamen as a threat to their future careers at sea, and excluded Asian sailors, especially the Chinese, from its membership. During the $1880 \mathrm{~s}$, seamen were creating greater solidarity and unity of purpose among themselves, but in a narrower fashion that bifurcated the maritime community along racial lines. Most sailors involved in the coastal trade were whites, with Scandinavians predominating.

Despite its limited membership, several factors contributed to the successful creation of the Coast Seamen's Union. New opportunities opened up for those sailors who remained at sea aboard sailing vessels and steamships involved in coastal trading. Coastal trading held several advantages for seamen that deep sea sailing did not. The coastal shipping, especially aboard the vessels involved in the lumber trade, allowed seamen to work with sail instead of steam engines. Until the end of the nineteenth century, two-masted sailing schooners dominated the industry and were not completely replaced with steam schooners until the early twentieth century. The ships that sailed along the North American coast from California to Alaska also paid exceptionally well. ${ }^{59}$ For example, in the 1870s, John Cameron, still a young seaman, went to work aboard the Commodore, then engaged in the Puget Sound-San Francisco lumber trade. Cameron made $\$ 50$ dollars a month aboard the Commodore, almost twice what most sailors were making in the deep sea trade. Part of the reason coastal sailors in the lumber trade made more was because they had to load the cargo onto their vessels themselves without the assistance of longshoremen. ${ }^{60}$ Cameron's first cruise lasted about three months, and he received $\$ 150$ when the ship returned to San Francisco.

The coastal captains also had a better reputation among seamen than did the often brutal deep sea captains. The Commodore's master, Captain Gilmour, even helped Cameron to manage his money after his first cruise. According to Cameron, Gilmour sat him down and asked Cameron if his mother still lived. When Cameron answered yes, the captain said, "Well here's fifty dollars for her; fifty dollars for the bank; the rest you may

57 Taylor, The Sailors' Union of the Pacific, 53-54.

58 Stephen Schwartz, Brotherhood of the Sea: A History of the Sailors' Union of the Pacific, 1885-1985 (Oxford, UK: Transaction Books, 1986), 4-7; Taylor, The Sailors Union of the Pacific, 38-45.

59 Ibid., 16-17; K. Jack Bauer, "Pacific Coastal Commerce in the American Period," Journal of the West 20 (July 1981), 3:12; Karl Kortum, "Anals of the Pacific Steam Schooners," Sea History 83 (Winter 1997-98):40.

60 Karl Kortum and Roger Olmstead, “...it is a dangerous-looking place: Sailing Days on the Redwood Coast," 60 (March 1971) 1:45; Kortum, Annals of the Pacific Steam Schooners, 40-42; Schwartz, Brotherhood of the Sea, 6. 
use as you please." Gilmour then took Cameron to the Odd Fellows' Bank and deposited $\$ 50$ dollars into Cameron's account. Captain Gilmour also protected his men from San Francisco's crimps and boarding agents. Cameron witnessed Gilmour threaten to throw a debt collector off his ship when the man came aboard to collect money from a sailor who owed him. ${ }^{61}$ Coastal vessels usually did their own hiring and did not go through boarding agents and crimps to get their crews. This practice allowed seamen to keep most of their money, as boarding agents and crimps usually charged outrageous commissions and fees for their services, often putting sailors into debt. ${ }^{62}$ Coastal shipping also allowed sailors to spend more time in their home port.

Most cruises up and down the coast lasted only two or three months before returning home. These short cruises allowed seamen a more stable and regular presence in port. Although gone for periods of time, coastal seamen were not transient, which allowed them to become members of shoreside communities, not just temporary residents of a port's "sailortown." With more money in their pockets, and more permanent residence on shore, sailors found that they could more easily start and maintain a stable family life. ${ }^{63}$ In 1923, economist Paul S. Taylor wrote, "sailors say the proportion who are married and have families — among the coasting seamen particularly — is considerably larger than thirty years ago."64 During the late nineteenth century, coastal trading allowed Pacific seamen to begin to live more settled familial lives. The ability for seamen to start a family was an important one. With the demand for sailing skills rapidly declining in the later part of the nineteenth century, the manly identity associated with those skills was also in decline. Although family life was not directly related to the manliness associated with the sea, sailors' ability to support a family was due to their maritime occupation. Their manly skills at sea might have been disappearing, but at the end of the nineteenth century coastal sailors could lay claim to the manliness associated with raising and supporting a family. A more stable life on land also allowed coastal seamen the ability to form more stable community relationships with both seamen and landsmen. With more money and permanent residence in port towns, "These men wear good clothes when they come ashore, have some money in the bank, live in good sailor boardinghouses or uptown, attend the better amusements which the cities afford, and, if met on the street, would not be distinguished from other good citizens who work ashore." 65 Permanent residences in port towns also allowed coastal seamen to maintain labor organizations on land. In this way they also associated with landsmen's labor organizations along the West Coast, where they were heavily influenced by the anti-Chinese attitudes held by most unions and labor activists. ${ }^{66}$ With families to feed, seamen looked to new strategies in

61 Farrell, John Cameron's Odyssey, 133-135.

62 Schwartz, Brotherhood of the Sea, 4-6.

63 Sager, Seafaring Labour,

64 Taylor, The Sailors' Union of the Pacific, 17.

65 Taylor, The Sailors' Union of the Pacific, 17.

66 Schwartz, Brotherhood of the Sea, 13-14; Alexander Saxton, The Indispensable Enemy: Labor and the Anti-Chinese Movement in California (Berkeley: University of California Press, 1971), 113-156. 
order to better their working conditions, protect and redefine their manly identity, and create a new maritime community.

The ethnic make-up of coastal seamen also played a role in union formation. Although the coasting community had a diverse population, the vast majority consisted of Scandinavian and other white seamen. This was especially true for the enormous lumber fleet, where 40 percent were Scandinavian, 11 percent were Finnish, 10 percent were German, 8 percent were American, and the rest were from other European nations. Scandinavians were so prevalent that sailors jokingly referred to the lumber fleet as "California's Scandinavian Navy."67 During the late nineteenth century, Scandinavia was a world center of progressive politics. When Scandinavian sailors came to the United States, they brought with them the ideologies of socialism and syndicalism that were capturing the attention of Europeans, making the coastal trade a fertile ground for union organization and action. ${ }^{68}$

In 1884, coastal sailors' wages went from \$30 a month to \$25 a month. With sailors used to making higher wages, and many starting families, the wage decrease proved too much to bear. On 6 March 1885, angry sailors who gathered on the Folsom Street wharf agreed to create the Coast Seamen's Union, and immediately went on strike for higher wages. By 14 March, the union had succeeded in securing a raise to $\$ 30$ a month from most of the ship operators in San Francisco, and several vessels shipped out with full union crews. The union also created its own shipping master so that members no longer had to rely on unscrupulous crimps and boarding agents to find work. Although initially limited to men aboard sailing vessels that operated in coastal waters, the Coast Seamen's Union laid the foundation for further maritime union activity in the Pacific. Andrew Furuseth, a Norwegian immigrant sailor who became the leader of the Coast Seamen's Union, wrote about the goals of the union: "Our aims had application to all seamen of our race, and, therefore, we have steadily kept in mind that this coast was but a small part, and that, whatever success we might attain here, it would only be temporary, unless our ideals and our purposes could be extended to all seamen, not only in this country, but in Europe." 69 Although primarily interested in protecting white seamen, the Coast Seamen's Union realized that industry-wide cooperation was necessary for union success, and the labor organization extended its memberships to "colored" seamen on the coast on 1 April 1885. On 10 April, the union also decided to allow deep water sailors to join. Non-Asian sailors' animosity towards the Chinese, however, was too deeply ingrained in the maritime community, and at a meeting in December 1885, the union members refused to include Chinese seamen. Many coastal sailors had left deep sea sailing because of Chinese wage competition, and they wanted to protect their new occupations from similar circumstances. In 1886, the Coast Seamen's Union assisted the coastal seamen aboard steam vessels in creating the Steamship Sailors Protective Union. In 1891, the 3,000 member Coast Seamen's and the 1,000 Steamship Sailors Protective Union merged to create the Sailors' Union of the Pacific, uniting seamen aboard sailing

67 Kortum, "Annals of the Pacific Steam Schooners," 40.

68 Schwartz, Brotherhood of the Sea, 2, 6.

69 Taylor, The Sailors' Union of the Pacific, 53-54. 
vessels and steamships into a single organization for the first time. Once again, however, Chinese sailors were excluded. ${ }^{70}$

The creation of the Coast Seamen's Union and the Sailors' Union of the Pacific represented several important changes in the maritime industry. The unions represented the creation of a Pacific maritime community related to, but separate from, the traditions and culture created by Atlantic seamen prior to the nineteenth century. The creation of more shipyards in the Pacific and the rise of new urban centers, especially on the North American west coast, made Pacific seamen a native presence. ${ }^{71}$ The Coast Seamen's Union and Sailors' Union of the Pacific's goals illustrated that Pacific seamen faced challenges unique to their maritime work environment. Steamships altered the maritime industry worldwide during the nineteenth century. Due to the greater number of steamships in their ocean in the nineteenth century, Atlantic seamen felt the impact of steam first and most profoundly. The Pacific, however, had a native Asian workforce willing to work for lower wages than non-Asian seamen. The presence of thousands of mostly unskilled Asian sailors aboard the steamships of large shipping companies contributed to non-Asian seamen's bias against steam and Asians in the Pacific. Unimpressed with Asian sailing credentials during the mid-nineteenth century, sailor animosity increased by the end of the 1880s. Sailors dedicated to working with canvas linked steam technology with unskilled, cheap Asian labor, and non-Asians who worked aboard steam vessels saw Asian men as a threat to their livelihood. The Chinese represented the single largest Asian presence aboard American vessels and so bore the brunt of anti-Asian sentiment from the non-Asians who sailed under the U.S. ensign. The anti-Chinese movements started by working-class leaders and organizations along the west coast of the U.S. also influenced non-Asian Pacific seamen's perception of the Chinese. The combined presence of tens of thousands of Chinese seamen and steam technology in the Pacific created a dilemma for non-Asian sailors that threatened to deskill, devalue, and replace them and their maritime community and identity. In order to protect their jobs, their manly identity, and their labor culture non-Asian seamen decided to unite under the union banner.

In 1885 , non-Asian seamen successfully created a lasting maritime union movement in the Pacific. Union activity allowed non-Asian seamen to protect themselves economically, demand better working conditions at sea, and create a labor community and culture with men who held many of the same ideals about what it meant to be a sailor. Non-Asian seamen created a new maritime community in the Pacific with the founding of their unions, but it was a community that was far narrower than in previous decades or centuries. While sailors never created a racial utopia aboard sailing ships, they did express a racial tolerance that allowed whites, blacks, Pacific Islanders, and, to a far lesser degree, Asians to serve together aboard vessels in the Pacific. Steam

70 Schwartz, Brotherhood of the Sea, 10-22; Taylor, The Sailors' Union of the Pacific, 46-49, 57-65.

71 Bauer, "Pacific Coastal Commerce in the American Period," 11-14; Thomas R. Cox, "Single Decks and Flat Bottoms: Building the West Coast's Lumber Fleet, 1850-1929," 20 Journal of the West (July 1981):65-72. 
and the seemingly sudden appearance of large numbers of Chinese at sea, however, created a new era of racial intolerance and exclusion in the Pacific. When maritime missionary John B. Romeyn stated in 1819 that maritime commerce "makes those engaged in its pursuits citizens of the world. It subdues their national prejudices, and overcomes their local feelings," he could not have foreseen the changes that would occur to the sailing profession in the Pacific during the second half of the nineteenth century. ${ }^{72}$ By 1885 , seamen in the Pacific neither subdued their national prejudices nor overcame their local feelings. A clear line between Asians and non-Asians had been drawn. Everyone in the maritime industry participated in the dissolution of racial tolerance and maritime traditions and culture at sea. Employers eagerly deskilled labor at sea by converting to steam propulsion and hired cheaper, less-skilled Asian seamen over their non-Asian counterparts; Asian seamen willingly worked for less money and refused to adopt the maritime customs they found on American and European vessels; and nonAsian seamen refused to acknowledge the contributions and skills of Asian sailors and ultimately excluded them from the non-Asian maritime community. By the end of the nineteenth century, the maritime labor force was bitterly divided and racially antagonistic.

72 John B. Romeyn, D.D., A Sermon Delivered in the Middle Dutch Church, On the Evening of the Lord's Day, March 21, 1819, for the Benefit of the New York Marine Missionary Society (New York: J. Seymour, 1819), 12. 
